http://revped.ise.ro

\title{
SELF-REGULATION RESEARCH IN THE CONTEXT OF EDUCATIONAL NEUROSCIENCE - A SYSTEMATIC REVIEW
}

CERCETĂRI ASUPRA AUTOREGLĂRII ÎN CONTEXTUL NEOUROŞTIINTTEI EDUCATIIEI - O ANALIZĂ SISTEMATICĂ

\section{Violeta Maria CARAGEA, Lucian VOINEA, Miruna Luana MIULESCU}

\author{
Journal of Pedagogy, 2017 (2), 7 - 25 \\ https://doi.org/10.26755/RevPed/2017.2/7
}

The online version of this article can be found at: http://revped.ise.ro/category/2017-en/

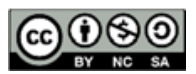

This work is licensed under the Creative Commons Attribution-NonCommercial-ShareAlike 4.0 International License. To view a copy of this license, visit http://creativecommons.org/licenses/by-nc-sa/4.0/ or send a letter to Creative Commons, PO Box 1866, Mountain View, CA 94042, USA.

Published by:

\section{INSTITUTUL DE ȘTIINȚE ALE EDUCAȚIEI}

http://www.ise.ro/

Further information about Revista de Pedagogie - Journal of Pedagogy can be found at:

Editorial Policy: http://revped.ise.ro/editorial-policy/

Author Guidelines: http://revped.ise.ro/the-writer-guide-2/ 


\title{
ABORDĂRI TEORETICE \\ SELF-REGULATION RESEARCH IN THE CONTEXT OF EDUCATIONAL NEUROSCIENCE - A SYSTEMATIC REVIEW
}

\author{
Violeta Maria CARAGEA* \\ Lucian VOINEA** \\ Miruna Luana MIULESCU***
}

\begin{abstract}
Self-regulation in school contexts is a subject that caught the attention of researchers from many disciplines. Educational neuroscience is an emerging research field aiming to bridge the neuroscientific knowledge and methodology with those of more consecrated research disciplines investigating learning and education, like psychology, sociology or education. Our paper investigates recent empirical studies exploring self-regulation in preK-12 educational contexts and which were identified as educational neuroscientific literature. As a result of an extensive search and filtering process conducted in conformity with the systematic review methodology, we found five articles that passed the predefined filtering criteria. Our findings suggest that this type of literature appeared mostly in the last decade with the occasion of new neuroscientific methodologies allowing conducting non-invasive advanced brain studies. The main self-regulation elements these studies focus on are academic motivation, attention orientation, self-perception on own mental abilities and behaviours, cognitive and emotional engagement in learning, social and task-related behaviour regulation. The methodologies used consisted mainly in self- or others-reported questionnaires, behavioural measures evaluation, academic performance measurement, computerized testing of cognitive abilities, physiological measures recordings (e.g. saliva or blood samples, heart rate), electroencephalography (EEG), and functional magnetic resonance imaging (fMRI). The samples included in the reviewed articles vary from preschool to primary, middle and high school students, comprising 376 participants in total. The reported research outcomes are rather limited but they also offer optimism regarding the possibilities to use neuroscientific methods for investigating self-regulation in an educational context. Various aspects regarding limitations of this type of research are discussed.
\end{abstract}

Keywords: educational neuroscience; school context; self-regulation; systematic review.

\footnotetext{
Institute of Education Sciences Bucharest, Romania;

* Researcher dr.; violeta.caragea@ise.ro;

** Researcher; lucian voinea@ise.ro;

*** Assistant Researcher; miruna.miulescu@ise.ro
} 


\section{Rezumat}

Auto-reglarea în contexte şcolare este un subiect care a preocupat mul $i$ cercetători din variate discipline. Neuroştiin a educa iei este un domeniu emergent de cercetare care îşi propune să conecteze cunoaşterea şi metodologia specifică neuroștiin elor cu cea a altor domenii mai consacrate în studiul învă ării şi educa iei, precum psihologia, sociologia sau ştiin ele educa iei. Lucrarea de fa ă analizează studiile empirice recente ce explorează auto-reglarea în sistemul preuniversitar şi care se încadrează în literatura de neuroştiin ă a educa iei. In urma unei căutări şi filtrări laborioase, conforme cu metodologia analizei sistematice, am identificat cinci articole care au trecut de criteriile de filtrare predefinite. Rezultatele analizei noastre sugerează că acest tip de literatură este publicat în mod special în ultimul deceniu, fiind prilejuit de noile metodologii din neuroştiin ă care au facilitat realizarea de studii non-invazive avansate la nivelul creierului uman. Principalele elemente ale auto-reglării studiate în aceste articole se referă la orientarea şi reglarea motiva iei pentru învă are, orientarea aten iei, modul de percepere a propriilor abilită i mentale şi comportamente, gradul de implicare cognitivă şi emo ională în învă area şcolară şi autocontrolul comportamentului social şi cel privind implicarea în sarcinile şcolare. Metodologiile utilizate au constat în principal in aplicarea de chestionare auto-completate sau completate de către ceilal $i$, evaluări comportamentale, testarea performan ei academice, teste computerizate vizând abilită i cognitive, înregistrări de indicatori fiziologici (precum probe de salivă, sânge sau bătăile inimii), electroencefalografie (EGG) şi imagistică func ională prin rezonan ă magnetică (RMN func ional). Eşantioanele incluse în aceste studii variază de la elevi preşcolari la cei din învă ământul primar, gimnazial şi liceal, însumând 376 de participan i în total. Rezultatele de cercetare raportate sunt mai degrabă limitate, însă oferă totodată optimism privind utilizarea metodelor de investigare din neuroştiin e pentru cercetarea auto-reglării în context şcolar. Diferite aspecte privind limitările acestui tip de cercetare sunt, de asemenea, discutate în acest articol. Cuvinte-cheie: analiză sistematică de literatură; auto-reglare; context şcolar; neuroştiin a educa iei. 


\section{Introduction}

Educational neuroscience is an emerging research field with a history of no longer than one decade. Although there were many attempts to connect the knowledge from fields such as cognitive psychology to that from cognitive neuroscience when approaching subjects of interest in education (Mareschal, Butterworth \& Tolmie, 2013), such as the mechanisms of the learning processes, this was always perceived as "a bridge too far" (Bruer, 1997) to be used by researchers and even practitioners in education.

But, as new neuroscientific methodologies of non-invasive investigation on humans developed in the last decades, this "bridge" seems to have formed more appropriate avenues and therefore allowed researchers to find better ways to explore education specific subjects using neuroscientific knowledge. Using electroencephalography or functional magnetic resonance imaging to explore the impact of various education-related stimuli such as cognitive or social abilities training on students is no longer a strange or extravagant research initiative but rather the norm for researchers willing to find more profound ways to explore how the brain works in different educational contexts (Caragea et al., 2017).

Self-regulation is defined in the psychological literature as a process of selfmanagement, based on a set of abilities that a certain person uses in order to monitor and control his/her own emotions, thoughts, or behaviour, as to better suit the goals that the person established for himself and/or to better adapt to different contexts. It includes abilities related to self-observation and awareness, self-evaluation, self-control, self-modification, self-motivation, attentional orientation (Woltering \& Lewis, 2009; Posner, Rothbart \& Tang, 2013).

In education, we find the concept of self-regulated learning, which is a process aimed at achieving certain learning objectives by taking control of one's learning and guiding it as best as it can. The main abilities involved, besides the ones specified above, are learning-specific: establishing specific objectives; planning and monitoring activities; selecting and using specific strategies; using feedback in order to better reach objectives (Zimmerman, 1990).

The current study aims to understand how educational neuroscientific literature approaches the self-regulation research topic in general, in school contexts. In order to do that we are looking at studies that investigated various aspects of self-regulation (e.g. motivation, attention, meta-cognition, behavioural selfcontrol) at the level of preK-12 students, using a mix of methods specific either to neuroscience or behavioural sciences. 
We will, therefore, address the following research questions to the abovementioned literature:

- How large is the contribution of educational neuroscience literature on exploring self-regulation in school contexts?

- What aspects of self-regulation are mostly studied in this area of research?

- What type of methodologies is preferred when studying self-regulation in educational neuroscience?

- What is the specific of the reported research outcomes of these empirical studies?

- What are the main limitations?

- What can be drawn as future perspectives?

In order to be able to answer all of these questions, we selected the systematic review as a good research method to help us achieve our predefined research aim (Roth, Ogrin \& Schmitz, 2015; Betihavas et al., 2016; Dion \& Restrepo, 2016).

\section{Methodology}

\subsection{Search Strategy}

In September 2017, a systematic search was conducted of the following international psychological, educational and neuroscientific electronic databases: PubMed, EBSCO, ERIC, and ProQuest. The Boolean operators "AND"/"OR"/"NOT"/"-related" were used to combine search terms including: "self-regulation", "school", and "neuro-".

A secondary search was conducted on screening for the most relevant journals in educational neuroscience currently - Trends in Neuroscience and Education (published by Elsevier) and Mind, Brain, and Education (published by Wiley). Social Cognitive and Affective Neuroscience journal (published by Oxford Academic) was also screened for relevant articles.

The search was limited to English articles only. The search for each database was conducted separately based on similar keywords combination as mentioned above. Abstracts were first screened to see if the entries meet the predefined criteria and then saved if they seemed to have potential to be selected. A secondary more in-depth screening (including the full text of the paper) was consequently conducted. The references to these studies were also checked in order to identify additional papers fulfilling the inclusion criteria. The results from all searches were concatenated and duplicates were then removed. The results of the different search and filtering stages are exposed in Figure 1. 


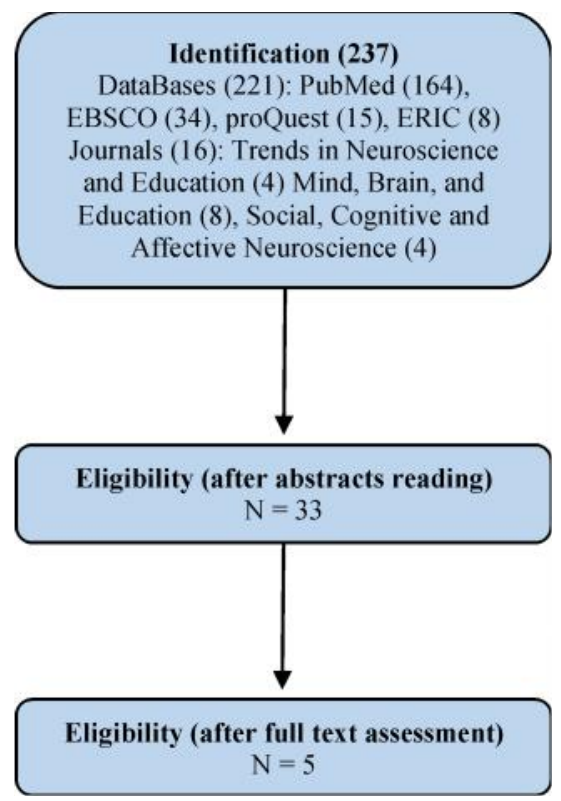

Figure 1. Flow diagram of the systematic review process

Each of the three authors was involved in the screening of databases, one being in charge with education and psychology related databases (EBSCO, ERIC, and ProQuest), one with PubMed biomedical research database, and one searched more targeted in three selected journals considered as most relevant for the review focus. A common database was built to integrate the results after the exclusion phase, thus helping to identify potential duplicates.

\subsection{Filtering Criteria}

The main inclusion criteria used to search for relevant studies referred to:

- Peer review empirical studies (not reviews or another type of research) that investigated self-regulation in an educational context having also a focus on brain research specific input.

The following exclusion criteria were used:

- Published in the last 10 years (starting with January 2007);

- Full text in the English language;

- Only samples of students from 3 to 18 years old approximately (preK to 12-grade students);

- Using neuroscientific methods of investigation (measuring physiological input that is related to how the human nervous system functions);

- Approaching aspects that can be inferred to the educational context. 


\subsection{Search Outcomes}

The search for each stream of articles had different results. PubMed database generated the largest number of entries (164), followed by EBSCO (34), ProQuest (15), and ERIC (8). The most targeted search, in the three scientific journals targeted, generated a total of 16 results. Therefore the filtering process, according to the exclusion criteria, included 237 titles. Generally, by only reading the abstracts, the filters could be applied, but in cases where some elements were not clear, the full text was examined for significant details (mostly, for the information regarding sample characteristics, neuroscientific methods use, educational context relatedness and quality of the journal). This was the case for a total of 33 articles.

The filtering process resulted in a number of only five articles that met all the criteria. From our observations, many other relevant articles were either a review or were not using basic neuroscientific methods or the samples were other than preK-12 students (mostly undergraduates). In the case of the criterion regarding educational context relevance, all the three researchers shared their opinions on the articles that raised this question until a consensus was reached.

\subsection{Data Extraction}

All three researchers contributed to the extraction and categorization of data. An online collaborative spreadsheet was built in order to have all raw data put together for comparison. Each column was used as a category and each row was dedicated to one article. The categories used for extracting data were: author(s), year \& journal; the aim of the study; tested variables; samples; methodology; reported outcomes; reported limitations; future research perspectives; educational implications (Table 1).

As a secondary analysis of these data, patterns of information were identified and then categorized as summaries of a systematic synthesis. The following themes were, therefore, approached: study characteristics, self-regulation elements addressed, methods and instruments, outcomes and educational implications, study limitations, and future research perspectives.

\section{Results}

\subsection{Study Characteristics}

The systematic review of the empirical studies investigating self-regulation in school contexts with the help of neuroscientific knowledge and methods comprised five studies. All of these studies where published in educational 
neuroscience dedicated journals ( 3 in Mind, Brain, and Educational journal and 2 in Trends in Neuroscience and Education journal), within the last ten years. All three elements that are a subject of self-regulation were approached in these studies: emotional, cognitive, and behavioural regulation. Nevertheless, the approaches and foci were diverse. The samples of all five studies totalled 376 participants with 36 being the smallest sample and 164 the largest with a wide age spectrum (one study involved pre-schoolers, one a mix of preschoolers and primary school students, one middle school students and two studies tested high school students). The research studies included were conducted in US (2), Spain, UK, and Finland. The methodology of all empirical studies was based on a mix of methods - ones that are more specific to behavioural sciences (such as self- or others-reported questionnaires, testing

Table 1a. Summary of included studies in the systematic review (part 1)

\begin{tabular}{|c|c|c|c|c|}
\hline $\begin{array}{c}\text { Author(s), } \\
\text { Year \& } \\
\text { Journal }\end{array}$ & Aim of the study & Tested variables & Samples & Methodology \\
\hline $\begin{array}{l}\text { Checa et al., } \\
\text { 2008; in Mind, } \\
\text { Brain, and } \\
\text { Education }\end{array}$ & $\begin{array}{l}\text { To examine the } \\
\text { role of individual } \\
\text { differences in } \\
\text { neurocognitive and } \\
\text { temperamental } \\
\text { systems of self- } \\
\text { regulation in early } \\
\text { adolescents' social } \\
\text { and academic } \\
\text { competence. }\end{array}$ & $\begin{array}{l}\text { Alerting attention; } \\
\text { orienting attention; } \\
\text { executive attention; } \\
\text { effortful control (EC); } \\
\text { negative affect; } \\
\text { extraversion/ } \\
\text { Surgency; } \\
\text { social status } \\
\text { (appreciation / } \\
\text { rejection); } \\
\text { schooling skills; } \\
\text { school grades. }\end{array}$ & $\begin{array}{l}\mathrm{N}=69 \text {, Mean } \\
\text { age: } 12.7 \\
\text { years } \\
\text { SD: } 0.65 ; 34 \\
\text { boys; Spanish } \\
\text { high school } \\
\text { students. }\end{array}$ & $\begin{array}{l}\text { Computerized } \\
\text { testing of } \\
\text { attention } \\
\text { networks (based } \\
\text { on specific } \\
\text { neural correlates } \\
\text { theories); } \\
\text { self/peer/parent } \\
\text { questionnaires; } \\
\text { school grades } \\
\text { measures. }\end{array}$ \\
\hline $\begin{array}{l}\text { Fisher et al., } \\
2009 ; \text { in Mind, } \\
\text { Brain, and } \\
\text { Education }\end{array}$ & $\begin{array}{l}\text { To test the relation } \\
\text { between academic } \\
\text { motivational } \\
\text { characteristics and } \\
\text { certain } \\
\text { neurophysiological } \\
\text { systems that are } \\
\text { thought to underlie } \\
\text { the processing of } \\
\text { successes and } \\
\text { failures. }\end{array}$ & $\begin{array}{l}\text { Academic motivation; } \\
\text { motivation orientation/ } \\
\text { regulation; } \\
\text { causal attributions of } \\
\text { performance; } \\
\text { error-related negativity } \\
\text { (ERN) amplitude; } \\
\text { anterior cingulate } \\
\text { cortex (ACC)-based } \\
\text { error-monitoring } \\
\text { system. }\end{array}$ & $\begin{array}{l}\mathrm{N}=36 ; 3 \text { rd to } \\
\text { 5th-grade US } \\
\text { students ( } 22 \\
\text { male), Mean } \\
\text { age: } 9.53 \\
\text { years, } \\
\mathrm{SD}=0.84 .\end{array}$ & $\begin{array}{l}\text { Electroencephalo } \\
\text { graphy (EEG) - } \\
\text { Event-Related } \\
\text { Potentials } \\
\text { (ERP); } \\
\text { Computerized } \\
\text { testing; } \\
\text { self-reported } \\
\text { questionnaires; } \\
\text { intelligence } \\
\text { measure; } \\
\text { academic } \\
\text { performance } \\
\text { measure. }\end{array}$ \\
\hline
\end{tabular}




\begin{tabular}{|c|c|c|c|c|}
\hline $\begin{array}{c}\text { Author(s), } \\
\text { Year \& } \\
\text { Journal }\end{array}$ & Aim of the study & Tested variables & Samples & Methodology \\
\hline $\begin{array}{l}\text { Lisonbee et al., } \\
2010 \text {; in Mind, } \\
\text { Brain, and } \\
\text { Education }\end{array}$ & $\begin{array}{l}\text { To examine the } \\
\text { contribution of } \\
\text { Hypothalamic- } \\
\text { Pituitary-Adrenal } \\
\text { (HPA) and } \\
\text { Sympathetic } \\
\text { Nervous System } \\
\text { (SNS) activity to } \\
\text { children's } \\
\text { behavioural } \\
\text { regulation abilities } \\
\text { in a classroom } \\
\text { setting. }\end{array}$ & $\begin{array}{l}\text { Regulation difficulties; } \\
\text { effortful control; } \\
\text { delay of gratification; } \\
\text { inhibitory control/slow } \\
\text { down motor; } \\
\text { level of cortisol; } \\
\text { level of alpha-amylase; } \\
\text { Control variables: } \\
\text { age; gender; socio- } \\
\text { economic status; } \\
\text { minority status; } \\
\text { classroom group size; } \\
\text { teacher sensitivity. }\end{array}$ & $\begin{array}{l}\mathrm{N}=186 \text { USA } \\
\text { children in } 4- \\
\text { year-old } \\
\text { classrooms in } \\
12 \text { full-day } \\
\text { preschools: } \\
101 \text { boys, } \\
\text { mean age } \\
53.25 \text { months, } \\
66 \% \\
\text { Caucasian; }\end{array}$ & $\begin{array}{l}\text { Teachers and } \\
\text { parents reports; } \\
\text { Saliva sample } \\
\text { analysis (pre and } \\
\text { post Challenge } \\
\text { task) for } \\
\text { measuring the } \\
\text { levels of cortisol } \\
\text { and alpha- } \\
\text { amylase; } \\
\text { Observer reports } \\
\text { on CIS } \\
\text { (Caregiver } \\
\text { Interaction } \\
\text { Scale); Video } \\
\text { recording and } \\
\text { analysing of } \\
\text { children } \\
\text { behaviour } \\
\text { during the } \\
\text { Challenge tasks. }\end{array}$ \\
\hline $\begin{array}{l}\text { Sanger \& } \\
\text { Dorjee, 2016; } \\
\text { in Trends in } \\
\text { Neuroscience } \\
\text { and Education }\end{array}$ & $\begin{array}{l}\text { To investigate the } \\
\text { impact of a } \\
\text { mindfulness } \\
\text { training on } \\
\text { markers of } \\
\text { attention and } \\
\text { metacognition in } \\
\text { adolescents }\end{array}$ & $\begin{array}{l}\text { Mindful disposition; } \\
\text { self-perception on own } \\
\text { mental abilities and } \\
\text { behaviours; } \\
\text { mind wandering; } \\
\text { curriculum enjoyment; } \\
\text { attention to stimuli; } \\
\text { inhibition of stimuli; } \\
\text { cognitive load. }\end{array}$ & $\begin{array}{l}\mathrm{N}=40,16 \text { to } \\
18 \text { years, UK } \\
\text { students in } \\
\text { programs } \\
\text { awarded with } \\
\text { the highest } \\
\text { high school } \\
\text { qualifications. }\end{array}$ & $\begin{array}{l}\text { Self-reported } \\
\text { questionnaires } \\
\text { (pre and post- } \\
\text { test); } \\
\text { Behavioural } \\
\text { measures; } \\
\text { Computerized } \\
\text { tests; } \\
\text { Electroencephalo- } \\
\text { graphy (EEG). }\end{array}$ \\
\hline $\begin{array}{l}\text { Streb et al., } \\
2015 ; \text { in } \\
\text { Trends in } \\
\text { Neuroscience } \\
\text { and Education }\end{array}$ & $\begin{array}{l}\text { To test whether } \\
\text { children's } \\
\text { emotional arousal } \\
\text { is affected by } \\
\text { satisfaction of the } \\
\text { basic } \\
\text { psychological } \\
\text { needs as defined } \\
\text { by the self- } \\
\text { determination } \\
\text { theory (autonomy, } \\
\text { social relatedness, } \\
\text { and competence). }\end{array}$ & $\begin{array}{l}\text { Emotional arousal (as } \\
\text { ambulatory assessed } \\
\text { additional heart rate } \\
\text { increase); basic } \\
\text { psychological needs (as } \\
\text { social relatedness, } \\
\text { autonomy, and } \\
\text { competence) }\end{array}$ & $\begin{array}{l}\mathrm{N}=64 \\
\text { (kindergarten } \\
=6, \text { grammar } \\
\text { school grade } 1 \\
\text { and } 2=16, \\
\text { grammar } \\
\text { school grade } 3 \\
\text { and } 4=16, \\
\text { secondary } \\
\text { school =16; } \\
\text { boys= 32, } \\
\text { girls = 32). } \\
\text { Finland }\end{array}$ & $\begin{array}{l}\text { FMS (Freiburger } \\
\text { Monitoring } \\
\text { system)- } \\
\text { Analysis: } \\
\text { Accelerometry } \\
\text { and } \\
\text { electrocardio- } \\
\text { graphy (ECG). }\end{array}$ \\
\hline
\end{tabular}


Table 1b. Summary of included studies in the systematic review (part 2)

\begin{tabular}{|c|c|c|c|c|}
\hline $\begin{array}{l}\text { Author(s) } \\
\text { \& Year }\end{array}$ & $\begin{array}{l}\text { Reported } \\
\text { outcomes }\end{array}$ & $\begin{array}{c}\text { Reported } \\
\text { limitations }\end{array}$ & $\begin{array}{c}\text { Future research } \\
\text { perspectives }\end{array}$ & $\begin{array}{l}\text { Educational } \\
\text { implications }\end{array}$ \\
\hline $\begin{array}{l}\text { Checa et } \\
\text { al., } 2008\end{array}$ & $\begin{array}{l}\text { Executive attention } \\
\text { accounted for unique } \\
\text { variance only when } \\
\text { predicting grades in } \\
\text { mathematics; } \\
\text { Temperamental systems } \\
\text { of negative emotionality } \\
\text { showed a strong } \\
\text { association with poorer } \\
\text { schooling skills; } \\
\text { Parent-reported negative } \\
\text { affectivity was } \\
\text { associated with both low } \\
\text { academic performance } \\
\text { and increased social } \\
\text { rejection in school; } \\
\text { Both self- and parent- } \\
\text { reported temperamental } \\
\text { EC were positively } \\
\text { related to all measures of } \\
\text { schooling skills and } \\
\text { academic achievement; } \\
\text { Parent-reported EC was } \\
\text { positively associated } \\
\text { with social appreciation } \\
\text { and negatively with } \\
\text { antisocial behaviour; } \\
\text { The relationship } \\
\text { between social } \\
\text { maladjustment and } \\
\text { poorer schooling } \\
\text { outcomes was mediated } \\
\text { by EC; } \\
\text { A significant correlation } \\
\text { was recorded between } \\
\text { the executive attention } \\
\text { score and parent- } \\
\text { reported EC. }\end{array}$ & $\begin{array}{l}\text { Measures of brain } \\
\text { function during } \\
\text { performance of } \\
\text { cognitive tasks to test } \\
\text { the connection between } \\
\text { activation of the brain } \\
\text { network and } \\
\text { behavioural regulation } \\
\text { and achievement at } \\
\text { school were not } \\
\text { included. }\end{array}$ & $\begin{array}{l}\text { Collecting } \\
\text { measures of brain } \\
\text { function during } \\
\text { performance of } \\
\text { cognitive tasks to } \\
\text { test the connection } \\
\text { between activation } \\
\text { of the brain } \\
\text { network and } \\
\text { behavioural } \\
\text { regulation and } \\
\text { achievement at } \\
\text { school; } \\
\text { The relationship } \\
\text { between either } \\
\text { performance in } \\
\text { cognitive tasks or } \\
\text { reports of } \\
\text { children's EC and } \\
\text { achievement, and } \\
\text { socio-emotional } \\
\text { regulation in } \\
\text { cross-sectional } \\
\text { and/or } \\
\text { longitudinal } \\
\text { studies along the } \\
\text { periods of major } \\
\text { development of } \\
\text { self-regulation; } \\
\text { Examination of } \\
\text { beneficial effects } \\
\text { of interventions } \\
\text { also affect } \\
\text { temperament and } \\
\text { academic } \\
\text { performance and } \\
\text { transfer to abilities } \\
\text { relevant for } \\
\text { schooling } \\
\text { competence such } \\
\text { as socio-emotional } \\
\text { regulation. }\end{array}$ & $\begin{array}{l}\text { Possibility to } \\
\text { design } \\
\text { interventions to } \\
\text { improve school } \\
\text { readiness; } \\
\text { Arguments for the } \\
\text { reduction of } \\
\text { teacher's negative } \\
\text { reactions; } \\
\text { Promotion of } \\
\text { support feelings; } \\
\text { Encouraging } \\
\text { students to use } \\
\text { more appropriate } \\
\text { coping strategies. }\end{array}$ \\
\hline
\end{tabular}




\begin{tabular}{|c|c|c|c|c|}
\hline $\begin{array}{l}\text { Author(s) } \\
\text { \& Year }\end{array}$ & $\begin{array}{l}\text { Reported } \\
\text { outcomes }\end{array}$ & $\begin{array}{c}\text { Reported } \\
\text { limitations }\end{array}$ & $\begin{array}{c}\text { Future research } \\
\text { perspectives }\end{array}$ & $\begin{array}{l}\text { Educational } \\
\text { implications }\end{array}$ \\
\hline $\begin{array}{l}\text { Fisher et } \\
\text { al., } 2009\end{array}$ & $\begin{array}{l}\text { Intrinsically oriented } \\
\text { students displayed larger } \\
\text { amplitude ERN } \\
\text { responses and made } \\
\text { more internally directed } \\
\text { attributions about their } \\
\text { task performance; } \\
\text { Students with high } \\
\text { intrinsic orientation } \\
\text { attribute performance to } \\
\text { personal control and } \\
\text { their error-monitoring } \\
\text { system was more } \\
\text { strongly engaged by } \\
\text { performance errors; } \\
\text { Students who attribute } \\
\text { their performance to } \\
\text { internal causes on the } \\
\text { task were more } \\
\text { intrinsically motivated } \\
\text { and had higher grades } \\
\text { (GPAs). }\end{array}$ & $\begin{array}{l}\text { Small data set; } \\
\text { Limited range of } \\
\text { motivation orientation }\end{array}$ & $\begin{array}{l}\text { More } \\
\text { neurocognitive } \\
\text { studies examining } \\
\text { error monitoring } \\
\text { and educational } \\
\text { issues related } \\
\text { motivation; } \\
\text { Exploring the } \\
\text { parallels between } \\
\text { motivational } \\
\text { processes and the } \\
\text { ACC-based error- } \\
\text { monitoring system } \\
\text { (as indexed by the } \\
\text { ERN response); } \\
\text { Explaining why } \\
\text { intrinsic } \\
\text { motivation } \\
\text { orientation would } \\
\text { be associated with } \\
\text { a larger ERN. }\end{array}$ & $\begin{array}{l}\text { Helping teachers } \\
\text { understand how } \\
\text { academic } \\
\text { motivation may be } \\
\text { related to } \\
\text { individual } \\
\text { differences in } \\
\text { error-monitoring } \\
\text { behaviour and error } \\
\text { processing patterns. }\end{array}$ \\
\hline $\begin{array}{l}\text { Lisonbee et } \\
\text { al., } 2010\end{array}$ & $\begin{array}{l}\text { Girls showed better } \\
\text { delay of gratification } \\
\text { than boys; } \\
\text { Minority children } \\
\text { performed more poorly } \\
\text { on the delay of } \\
\text { gratification task; } \\
\text { Higher SES children and } \\
\text { older children were } \\
\text { better able to slow down } \\
\text { their drawing during the } \\
\text { task; } \\
\text { Children with higher } \\
\text { cortisol and alpha- } \\
\text { amylase levels showed } \\
\text { more difficulty slowing } \\
\text { down during the drawing } \\
\text { task than did children } \\
\text { with lower levels of } \\
\text { both; } \\
\text { The successful delay of } \\
\text { gratification requires } \\
\text { that the child puts to } \\
\text { good use the resources } \\
\text { of the central nervous } \\
\text { system; } \\
\text { The nervous systems of } \\
\text { better functioning } \\
\text { children are more at rest } \\
\text { when demands are not } \\
\text { placed on them. }\end{array}$ & $\begin{array}{l}\text { The methodological } \\
\text { approach to assessing } \\
\text { physiological activity } \\
\text { was the biggest } \\
\text { limitation; } \\
\text { The } 30 \text {-min long } \\
\text { challenge task and 30- } \\
\text { min "recovery" period } \\
\text { may not be ideal } \\
\text { durations for assessing } \\
\text { physiological } \\
\text { reactivity; } \\
\text { It is difficult to } \\
\text { ascertain exactly what } \\
\text { each physiological } \\
\text { measure is assessing } \\
\text { because of timing } \\
\text { differences; } \\
\text { It is impossible to } \\
\text { ascertain direction of } \\
\text { effect or dismiss } \\
\text { the effect of third } \\
\text { variables contributing } \\
\text { to both physiological } \\
\text { activity and } \\
\text { behavioural regulation. }\end{array}$ & $\begin{array}{l}\text { Examining } \\
\text { cultural, societal, } \\
\text { or biological } \\
\text { influences that } \\
\text { may account for } \\
\text { sAA differences } \\
\text { across groups; } \\
\text { Making clearer } \\
\text { sense of the } \\
\text { results by studying } \\
\text { patterns of } \\
\text { stability or change } \\
\text { in physiological } \\
\text { measures across } \\
\text { behavioural } \\
\text { assessments; } \\
\text { Studying HPA and } \\
\text { SNS activity } \\
\text { together to more } \\
\text { fully understand } \\
\text { how different } \\
\text { physiological } \\
\text { systems shape } \\
\text { behaviour. }\end{array}$ & $\begin{array}{l}\text { Increasing our } \\
\text { understanding of } \\
\text { how physiological } \\
\text { activity may shape } \\
\text { self-regulation in } \\
\text { ways that } \\
\text { contribute to } \\
\text { children's abilities } \\
\text { to effectively learn } \\
\text { in classrooms and } \\
\text { function in social } \\
\text { settings. }\end{array}$ \\
\hline
\end{tabular}




\begin{tabular}{|c|c|c|c|c|}
\hline $\begin{array}{l}\text { Author(s) } \\
\text { \& Year }\end{array}$ & $\begin{array}{l}\text { Reported } \\
\text { outcomes }\end{array}$ & $\begin{array}{c}\text { Reported } \\
\text { limitations }\end{array}$ & $\begin{array}{c}\text { Future research } \\
\text { perspectives }\end{array}$ & $\begin{array}{l}\text { Educational } \\
\text { implications }\end{array}$ \\
\hline $\begin{array}{l}\text { Sanger \& } \\
\text { Dorjee, } \\
2016\end{array}$ & $\begin{array}{l}\text { Mindfulness training for } \\
\text { adolescents, delivered by } \\
\text { schoolteachers, can have } \\
\text { a positive impact on } \\
\text { attention processing. } \\
\text { Specifically, it leads to } \\
\text { less concentration } \\
\text { lapses, relying less on } \\
\text { worry-based motivations } \\
\text { to work; reducing } \\
\text { superstitious and self- } \\
\text { punishing beliefs in } \\
\text { students' thought } \\
\text { content; increasing } \\
\text { ability to discriminately } \\
\text { inhibit responses to task- } \\
\text { irrelevant oddball } \\
\text { stimuli; greater self- } \\
\text { reported enjoyment of } \\
\text { the programme and } \\
\text { changes in target } \\
\text { response accuracy; no } \\
\text { significant results on the } \\
\text { investigation of P3 area } \\
\text { activation correlated } \\
\text { with cognitive load. }\end{array}$ & $\begin{array}{l}\text { The correlation } \\
\text { between target } \\
\text { accuracy and } \\
\text { mindfulness course } \\
\text { enjoyment may have } \\
\text { been confounded by } \\
\text { motivation; } \\
\text { There was a marginal } \\
\text { variance for changes in } \\
\text { metacognition, and } \\
\text { therefore inadvertent } \\
\text { selection bias may } \\
\text { have impacted the } \\
\text { results; } \\
\text { Does not include } \\
\text { follow-up } \\
\text { measurements to assess } \\
\text { the possibility of } \\
\text { emotion regulation } \\
\text { effects as subsequent to } \\
\text { improvements in } \\
\text { attention processing. }\end{array}$ & $\begin{array}{l}\text { Follow-up } \\
\text { measurements on } \\
\text { emotion } \\
\text { regulation of } \\
\text { former } \\
\text { mindfulness } \\
\text { training students; } \\
\text { Studying the } \\
\text { 'startle' effect } \\
\text { after mindfulness } \\
\text { training in } \\
\text { different sensorial } \\
\text { conditions (e.g. } \\
\text { sound stimuli); } \\
\text { Investigating links } \\
\text { between } \\
\text { modulations in N2 } \\
\text { are and } \\
\text { impulsivity, that } \\
\text { could be } \\
\text { correlated with } \\
\text { adolescents risk- } \\
\text { taking behaviour. }\end{array}$ & $\begin{array}{l}\text { Offers arguments } \\
\text { for introducing } \\
\text { mindfulness-based } \\
\text { training in schools, } \\
\text { as a facilitating } \\
\text { factor of } \\
\text { metacognitive and } \\
\text { attention skills of } \\
\text { adolescents, which } \\
\text { further lead to } \\
\text { greater academic } \\
\text { performance and } \\
\text { learning. }\end{array}$ \\
\hline $\begin{array}{l}\text { Streb et al., } \\
2015\end{array}$ & $\begin{array}{l}\text { Higher additional heart } \\
\text { rates, respectively } \\
\text { emotional arousal were } \\
\text { noticed at institutional } \\
\text { environments that put } \\
\text { emphasis on social } \\
\text { relatedness and } \\
\text { autonomy support; } \\
\text { Increased additional } \\
\text { heart rates were } \\
\text { registered in the case of } \\
\text { children who reported a } \\
\text { sense of competence. }\end{array}$ & $\begin{array}{l}\text { The FMS-analysis } \\
\text { overlooks emotional } \\
\text { arousal that } \\
\text { accompanies increases } \\
\text { in physical activity so } \\
\text { that not all emotional } \\
\text { events will be detected; } \\
\text { The FMS-analysis } \\
\text { cannot discriminate } \\
\text { between different } \\
\text { emotions (e.g. anger } \\
\text { and happiness). }\end{array}$ & $\begin{array}{l}\text { Studying the role } \\
\text { of self - } \\
\text { determination for } \\
\text { learning and } \\
\text { create learning } \\
\text { environments that } \\
\text { support autonomy, } \\
\text { social relatedness, } \\
\text { and competence. }\end{array}$ & $\begin{array}{l}\text { Bringing } \\
\text { arguments for } \\
\text { designing different } \\
\text { educational settings } \\
\text { that support } \\
\text { activities like } \\
\text { games, discussions, } \\
\text { and cooperative } \\
\text { learning; } \\
\text { Providing an } \\
\text { inspiring } \\
\text { environment so that } \\
\text { children associate } \\
\text { pleasure and } \\
\text { satisfaction with } \\
\text { their participation } \\
\text { in learning. }\end{array}$ \\
\hline
\end{tabular}

behaviours or cognitive abilities, academic performance reports, computerized testing) and others more specific to neuroscientific studies (e.g. assessment of physiological markers such as saliva, blood samples, or heart rate; electroencephalography, functional magnetic resonance imaging). All five studies reported some type of positive correlations regarding self-regulation and another type of tested variable, although they also reported limitations in 
their studies (mainly regarding the small number of participants or the methodology used). Three out of five studies formulated specific implications that their results can have on educational practice.

\subsection{Self-regulation Elements Addressed}

This section details the topics addressed by the studies and the variables used in order to measure the relationships hypothesized to exist between different aspects of self-regulation and different skills and emotional states that facilitate learning and social relationships.

The topics approached were very diverse: the contribution of physiological activity (HPA and SNS) to children's behavioural regulation abilities expected to relate to classroom and home measures of self-regulation (Lisonbee et al., 2010); the satisfaction of basic psychological needs and its effects on emotional arousal (Streb et al., 2015); the impact of a mindfulness training on markers of attention and metacognition in adolescents (Sanger \& Dorjee, 2016); the role of individual differences in neurocognitive and temperamental systems of self-regulation in early adolescents' social and academic competence (Checa et al., 2008), and the relation between academic motivational characteristics and certain neurophysiological systems that are thought to underlie the processing of successes and failures (Fisher et al., 2009).

Summing up, the main individual characteristics related to self-regulation addressed were: physiological and psychological activity, temperament, attention, metacognition, motivation and neurophysiological systems. The abilities and components regarding learning and social relationships were related to behavioural, attentional, metacognitive, temperamental, emotional, and motivational and cognitive (error processing) self-regulation.

For a more details view, variables studied can be clustered as follows:

- Behavioural elements: regulation difficulties, effortful control, delay of gratification, inhibitory control/slow down motor - Lisonbee et al., 2010.

- Cognitive aspects: attentional and metacognitive factors (more specific, in Sanger \& Dorjee, 2016 - mindful disposition, self-perception on own mental abilities and behaviours, mind wandering, curriculum enjoyment, attention to stimuli, inhibition of stimuli, cognitive load); general intellectual ability; attributional style of performance - Fisher et al., 2009; attentional and temperamental factors (alerting attention, orienting attention, executive attention, effortful control, negative affect, extraversion/surgency).

- Motivational factors: motivational orientation (intrinsic vs. extrinsic); neural correlates associated with motivation processing patterns (error-related negativity (ERN) amplitude, processed by the anterior cingulate cortex 
(ACC)-based error-monitoring system) - Fisher et al., 2009; satisfaction of basic psychological needs (relatedness - interaction with teacher and with peers, autonomy - freedom of choice with regard to the learning material and to the preferred way of learning, and competence - feeling of pride regarding personal achievement).

- Social factors: social status reflected as appreciation/rejection, schooling skills, or teacher sensitivity (Checa et al., 2008).

- Other physiological elements: level of cortisol - HPA activity and level of alpha-amylase - SNS activity, associated with emotional and behavioural self-regulation capacities; heart rate, associated with emotional arousal (Streb et al., 2015).

- Socio-demographic variables: age, gender, socioeconomic status of the family, minority status (Lisonbee et al., 2010), classroom group size.

- Academic performance: grades and other similar measures (Fisher et al., 2009; Checa et al., 2008).

\subsection{Methods and Instruments}

The focus of this systematic review was on identifying neuroscientific methods and their adapted instruments used on examining self-regulation in school contexts. Therefore, studies that only mentioned neuroscientific knowledge but used only surveys, psychological testing or classical behavioural data, did not pass our filtering process.

The way psychological behavioural methods are mixed with ones more specific to biomedical research it is, in fact, a characteristic and also an asset for educational neuroscience. Finding the best fit and the balance between behavioural and physiological evidence it is indeed a challenging act for researchers in this field, as this is also applied to children increasing thus ethical concerns on using human participants in empirical experiments.

In Table 2 a selective list of methods and their associated instruments willing to test self-regulation relevant variables are enumerated based on the data provided by the authors of the systematically reviewed studies. This could serve as an inspiration for researchers willing to further test self-regulation in school contexts.

\subsection{Outcomes and Educational Implications}

The emergence of new research techniques in neuroscience suitable for human non-invasive testing has produced a large body of neuroscientific studies of self-regulation over the past 10 years. The illustrated findings are significant because they extend the neuroscientific research of self-regulation beyond the laboratory settings and more close to the classroom environment. 


\section{Table 2. List of main methods and instruments for testing self-regulation used by the reviewed studies}

\begin{tabular}{|c|c|}
\hline Category of methods & Instruments \\
\hline $\begin{array}{l}\text { Self- or others-reported } \\
\text { questionnaires }\end{array}$ & $\begin{array}{l}\text { Social Competence and Behaviour Evaluation Scale-Short } \\
\text { Form (LaFrenière \& Dumas, 1996) - investigating self- } \\
\text { regulation; } \\
\text { Children's Behaviour Questionnaire (CBQ; Rothbart, } \\
\text { Ahadi, Hershey \& Fisher, 2001) - investigating temperament; } \\
\text { (Challenge Task) - measures of inhibitory control adapted } \\
\text { from the battery developed by Kochanska et al. (1996); } \\
\text { The Caregiver Interaction Scale (CIS; Arnett, 1989) - } \\
\text { assessing teacher insensitivity; } \\
\text { The Five-Facet Mindfulness Questionnaire (FFMQ) - } \\
\text { indicates mindful disposition; } \\
\text { The Meta-Cognitions Questionnaire - Adolescent Version } \\
\text { (MCQ-A) - records changes in students' perceptions of their } \\
\text { mental abilities and behaviours; } \\
\text { A mind wandering measure - records the amount of state mind } \\
\text { wandering participants experienced during an attention task; } \\
\text { Attention Network Test (ANT) - a modified version of the Fan } \\
\text { et al. (2002) adult ANT; } \\
\text { The Early Adolescence Temperament Questionnaire-Revised } \\
\text { (EATQ-R; Ellis and Rothbarth, 2001) } \\
\text { Harter's Scale of Intrinsic Versus Extrinsic Motivational } \\
\text { Orientation in the Classroom; } \\
\text { Attributional Style Concerning Flanker Task Performance. }\end{array}$ \\
\hline Physiological markers & $\begin{array}{l}\text { FMS (Freiburger Monitoring system) - Emotions analysis } \\
\text { Accelerometry and electrocardiography (ECG) }\end{array}$ \\
\hline $\begin{array}{l}\text { Electroencephalography } \\
\text { (EEG). }\end{array}$ & $\begin{array}{l}\text { The Event-Related Potential (ERP) analysis - post hoc } \\
\text { analysis of EEG measures of various brain areas associated } \\
\text { with specific cognitive functions }\end{array}$ \\
\hline Computerized testing & $\begin{array}{l}\text { The oddball test - an attention task used for computerized } \\
\text { testing of students; } \\
\text { Eriksen flanker task- computerized testing intended to elicit a } \\
\text { combination of successful and failed responses; }\end{array}$ \\
\hline Abilities testing & Wechsler Intelligence Scale for Children - 4th Edition; \\
\hline $\begin{array}{l}\text { School grades } \\
\text { measures. }\end{array}$ & Academic Performance (GPA scale). \\
\hline
\end{tabular}


Because the field is rather new and has been approached from a variety of interesting directions, this heterogeneity makes it difficult to summarize the existing discoveries. Nevertheless, the current studies represent attempts to explore how educationally relevant cognitive and motivational components may parallel neurophysiological reactions to performance outcomes in school settings. For instance, Fisher et al., 2009, set the stage for future research by testing the relation between academic motivational characteristics and specific neurophysiological systems that are believed to underlie successes and failures processing.

Although we should not over-interpret these findings, we must be cognizant that some may play an important role in shaping the future of education. For instance, one should think diligently about providing engaging learning environments which further lead to greater academic performance and learning. Given these facts, the authors offer arguments for introducing facilitating factors in schools (e.g. mindfulness-based training for students), or increasing teacher's awareness by helping them understand how some changes might have the potential to reduce conflict and elicit positive responses from students (Sanger \& Dorjee, 2016). These findings offer, therefore, a useful and interesting starting point for future investigations.

\subsection{Study Limitations}

The limitations of the studies, as identified and declared by the authors, were related to aspects of measurement (timing, interpretation), of some possible but un-investigated effects of confounding variables, selection bias, lack of follow-up measures to assess subsequent effects, and lack of measures to investigate brain function during performance of cognitive tasks and small data sets.

\subsection{Future Research Perspectives}

Despite the large research on self-regulation, there are still critical questions regarding research gaps that need to be addressed. For example, we are still confronted with the problem of generalizing from these results to the actual school environment. A proactive approach to research and research-toclassroom setting translation that includes neuroscientists, teachers, and school managers is an important next step. This is especially significant with regard to the large discrepancies between teacher's beliefs and self-regulated learning strategies (Sanger \& Dorjee, 2016).

Moreover, further investigation is a must in order to increase our understanding of the variables affecting self-regulation. For this reason, it has been stated 
that we must take into account a variety of factors and linkages that, to date, have not been sufficiently examined. Also, in some cases, it might be advisable to replicate the relevant physical characteristics in order to make clearer sense of the results (Lisonbee et al., 2010).

\section{Discussion}

This systematic review examined how educational neuroscientific literature approaches self-regulation research topics in school contexts. Due to the brief history of educational neuroscience literature (Mareschal, Butterworth \& Tolmie, 2013), we have found only a little number of empirical studies to pass our filtering criteria. Although, the number was higher in general as many other relevant and consistent studies were conducted on self-regulation in an educational setting using other samples than the ones we have selected for this review (mainly, consisting in higher education students).

\section{Self-Regulation in School Contexts}

Self-regulation is a subject well studied in disciplines like psychology and education, many testing instruments being developed over the years, some also exemplified in the studies here. Nevertheless, specific research subjects such as self-regulated learning (Zimmerman, 1990; Pintrich, 2004) are still a hot and debated topic in education. In this context, the new neuroscientific methods looking to find brain correlates that can bring new insights on more subtle elements of self-regulation (e.g. metacognition, mindset, engagement, conflicting stimuli inhibition) are currently under development and refinement. In this regard, as our review indicates, there are some specific abilities related to self-regulation that can be explored with neuroscientific methods, as for example the capacity to orient and focus own attention on specific environment/ internal stimuli (Sanger \& Dorjee, 2016; Checa et al., 2008); the capacity to inhibit first responses and adapt to a specific context (Lisonbee et al., 2010); the awareness of one's own emotions, thoughts, beliefs (Fisher et al., 2009).

\section{The Educational Neuroscience Promise}

As Butterworth and Tolmie formulated in their introductory chapter of one of the educational neuroscience pioneering books (Mareschal, Butterworth \& Tolmie, 2013), this new research field aims to provide insights on how we can help learners to achieve their learning potential "and to make learning more effective to all learners" (p. 2).

Taking this further, M.S.C. Thomas (2013) formulates some predictions regarding the evolution of educational neuroscience and of its impact in 
education. Thus, in the near future we can expect that this new discipline will help understanding reasons for why some methods work and some not, and we shall find ways to optimize learning but on a broader level; but on a far future, this could lead to some interesting and challenging phenomena, such as an "educational placebo effect", genetically personalized education, and thus will increase the need of a neuroscientific training for teachers.

Despite all these promises, we should keep aware that using neuroscientific methods in an educational setting has also many limitations. For example, using laboratory instruments of investigation (e.g. EEG or fMRI apparatus) is more difficult to assess subtle educational-specific elements as for example behavioural regulation in educational regular social contexts (Caragea et al., 2017).

\section{Limitations}

Regarding the limitations of our own study, we consider that although we tried to conduct a thorough search for relevant articles, some could have missed due to the fact that not all relevant databases were included in our search strategy. For example, for a future study, we are considering to use an aggregator such as Google Scholar (Dion \& Restrepo, 2016), which can offer a more thorough integration of potential relevant entries for our search.

Another limitation could have been the data extraction strategy, as each researcher had a slightly different approach in selecting the most relevant content to extract and also his or her way to analyse and formulate a synthesis of main ideas. For this, we used collaborative documents as to see in real time what the others are formulating and indicate them if some discrepancies would appear.

\section{Conclusions}

This systematic review, which included only five empirical studies, with a total of 376 participants, offered some insights regarding the type of relevant self-regulation variables and experimental designs that researchers from educational neuroscience can use in order to conduct specific studies in school contexts. The review indicates that this type of literature is in its dawn and that a successful mix between psychological tools and more neuroscientific physiological data related instruments, can be used to conduct self-regulation research in school contexts also for preK-12 students. We take note of the limitations these methods have, as they are very new in education research, but we are also keeping ourselves optimistic regarding their potential to facilitate further research insights on self-regulation in education and also on other education-related topics. 


\section{REFERENCES}

Betihavas V., Bridgman H., Kornhaber R. \& Cross M., (2016). The evidence for 'flipping out': a systematic review of the flipped classroom in nursing education, Nurse Educ. Today, 38, 15-21.

DOI: http://10.1016/j.nedt.2015.12.010.

Bruer, J. T. (1997). Education and the brain: A bridge too far. Educational Researcher, 26, 4-16,

https://doi.org/10.3102/0013189X026008004.

Caragea, V. M., Miulescu, M. L., Balica, M., \& Voinea, L. (2017). Educational Neuroscience: the Rise of a New Research Field in Educational Sciences. Ukrainian Pedagogical Journal, 3, 89-101.

Checa, P., Rodríguez-Bailón, R., \& Rueda, M. R. (2008). Neurocognitive and Temperamental Systems of Self-Regulation and Early Adolescents' Social and Academic Outcomes. Mind, Brain, and Education, 2, 177-187, https://doi.org/10.1111/j.1751-228X.2008.00052.x.

Dion, J.-S., \& Restrepo, G. (2016). A systematic review of the literature linking neural correlates of feedback processing to learning. Zeitschrift für Psychologie, 224(4), 247-256,

https://doi.org/10.1027/2151-2604/a000260.

Fisher, K. R., Marshall, P. J., \& Nanayakkara, A. R. (2009). Motivational Orientation, Error Monitoring, and Academic Performance in Middle Childhood:

A Behavioral and Electrophysiological Investigation. Mind, Brain, and Education, 3, 56-63,

https://doi.org/10.1111/j.1751-228X.2008.01053.x.

Karoly, P. (1993). Mechanisms of self-regulation: a systems view. Annual review of psychology, 44, 23-52,

https://doi.org/10.1146/annurev.ps.44.020193.000323.

Lisonbee, J. A., Pendry, P., Mize, J., \& Gwynn, E. P. (2010). HypothalamicPituitary-Adrenal and Sympathetic Nervous System Activity and Children's Behavioral Regulation. Mind, Brain, and Education, 4, 171-181, https://doi.org/10.1111/j.1751-228X.2010.01096.x.

Mareschal, D., Butterworth, B., \& Tolmie, A. (2013). Educational Neuroscience. Oxford, UK: Wiley Blackwell.

Pintrich, P. R. (2004). A Conceptual Framework for Assessing Motivation and Self-Regulated Learning in College Students. Educational Psychology Review, 16(4), 385-407,

https://doi.org/10.1007/s10648-004-0006-x.

Posner, M.I., Rothbart, M.K., \& Tang, Y. (2013). Developing self-regulation in early childhood. Trends in Neuroscience and Education, 2(3-4), 107-110, https://doi.org/10.1016/j.tine.2013.09.001. 
Roth, A., Ogrin, S., \& Schmitz, B. (2015). Assessing self-regulated learning in higher education: a systematic literature review of self-report instruments. Educational Assessment, Evaluation and Accountability, 21(1), 1-26.

https://doi.org/10.1007/s11092-015-9229-2.

Sanger, K.L., \& Dorjee, D. (2016). Mindfulness training with adolescents enhances metacognition and the inhibition of irrelevant stimuli: Evidence from event-related brain potentials. Trends in Neuroscience and Education, $5(1), 1-11$,

https://doi.org/10.1016/j.tine.2016.01.001.

Streb, J., Keis. O., Lau, M., Hille, K., Spitzer, M., \& Sosic-Vasic, Z. (2015). Emotional engagement in kindergarten and school children: A selfdetermination theory perspective. Trends in Neuroscience and Education, 4(4), 102-107,

https://doi.org/10.1016/j.tine.2015.11.001.

Thomas M.S.C. (2013). Educational neuroscience in the near and far future: Predictions from the analogy with the history of medicine. Trends in Neuroscience and Education, 2(1), 23-26,

https://doi.org/10.1016/j.tine.2012.12.001.

Woltering, S., \& Lewis, M. D. (2009). Developmental Pathways of Emotion Regulation in Childhood: A Neuropsychological Perspective. Mind, Brain, and Education, 3(3), 160-169,

https://doi.org/10.1111/j.1751-228X.2009.01066.x.

Zimmerman, B.J. (1990). Self-regulated learning and academic achievement: an overview. Educational Psychologist, 25(1), 3-17, https://doi.org/10.1207/s15326985ep2501_2.

The online version of this article can be found at: http://revped.ise.ro/category/2017-en/

\section{(2) (1)}

This work is licensed under the Creative Commons Attribution-NonCommercial-

ShareAlike 4.0 International License.

To view a copy of this license, visit http://creativecommons.org/licenses/by-ncsa/4.0/ or send a letter to Creative Commons, PO Box 1866, Mountain View, CA 94042.
Versiunea online a acestui articol poate fi găsită la: http://revped.ise.ro/category/2017-ro/

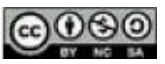

Această operă este pusă la dispozi ie sub licen a Creative Commons AttributionNonCommercial-ShareAlike 4.0 International.

Pentru a vedea o copie a acestei licen $e$, vizita $i$ http://creativecommons.org/licenses/by-ncsa/4.0/ sau trimite i o scrisoare către Creative Commons, PO Box 1866, Mountain View, CA 94042, SUA. 